\begin{tabular}{|l|l|l|}
\hline \multicolumn{2}{|c|}{ PublisherInfo } \\
\hline \hline PublisherName & $:$ & BioMed Central \\
\hline \hline PublisherLocation & $:$ & London \\
\hline \hline PublisherImprintName & $:$ & BioMed Central \\
\hline \hline
\end{tabular}

\title{
Aortic sclerosis outcome in the elderly
}

\begin{tabular}{||l|l|l||}
\hline \multicolumn{2}{|c||}{ ArticleInfo } \\
\hline \hline ArticleID & $:$ & 4085 \\
\hline \hline ArticleDOI & $:$ & $10.1186 /$ ccf-1999-1284 \\
\hline \hline ArticleCitationID & $:$ & 1284 \\
\hline \hline ArticleSequenceNumber & $:$ & 22 \\
\hline \hline ArticleCategory & $:$ & Paper Report \\
\hline ArticleFirstPage & $:$ & 1 \\
\hline \hline ArticleLastPage & $:$ & 4 \\
\hline \hline & $:$ & RegistrationDate : 1999-8-3 \\
ArticleHistory & $:$ & OnlineDate \\
\hline \hline ArticleCopyright & $:$ & Current Science Ltd1999-8-3 \\
\hline \hline ArticleGrants & $:$ & \\
\hline \hline ArticleContext & $:$ & 130541111 \\
\hline \hline
\end{tabular}




\section{Keywords}

Acute chest pain, cardiac troponin CK-MB, cTnT, myocardial injury

\section{Comments}

The Cardiovascular Health Study is a prospective study revealing important results as a consequence of the size of the study. Aortic sclerosis has traditionally been described as a benign condition and text books have been consistently reassuring about the clinical findings of a soft ejection murmur with normal character to the carotid pulse. In contrast, this study shows that aortic sclerosis appears to be a marker of coronary artery disease, and its presence may direct the physician to the need for further cardiac investigations. The pathophysiology is difficult to explain at present and awaits further investigation, but the epidemiology is convincing and aortic sclerosis should no longer be thought of as a trivial finding.

\section{Introduction}

It has long been felt that, in the absence of ventricular outflow tract obstruction, aortic sclerosis is a benign pathology. It can be characterized clinically by a soft ejection systolic murmur and normal carotid pulses. It affects approximately $25 \%$ of those over 65 years old, rising to nearly $50 \%$ in those over 85 years of age, compared with the very much lower incidence of hemodynamically important aortic stenosis ( $4 \%$ if $>85$ years old), which of course carries a much poorer prognosis. The Cardiovascular Health Study prospectively followed 5888 people over the age of 65 years in the USA, in order has been able to examine whether aortic sclerosis really is a benign condition, or perhaps just one end of the spectrum of aortic valve disease.

\section{Aims}

To determine whether aortic sclerosis (diagnosed by echocardiography) is associated with cardiovascular morbidity and mortality. 


\section{Methods}

The Cardiovascular Health Study prospectively followed two separate groups of subjects over the aged 65 or greater (a total of 5888 patients) during a one year period. Detailed history and examination accompanied by laboratory investigations, including hematology, biochemistry and echocardiography, were performed at baseline. Aortic sclerosis and stenosis were defined at baseline by certain echo characteristics. Coronary artery disease was defined at baseline if there was a history of myocardial infarction, angina, coronary artery bypass graft (CABG), or angioplasty. The mean follow-up period was five years for all subjects, and statistical analysis included identifying those factors already known to be related to aortic sclerosis or stenosis at baseline (age, gender, hypertension, smoking, raised cholesterol, and diabetes).

\section{Results}

Echocardiography revealed 3919 patients (70\%) with normal valves, $1610(29 \%)$ with sclerosis and $92(2 \%)$ with stenosis. There was a significant progressive increase in all deaths, cardiovascular deaths, and cardiovascular events when comparing normal to sclerotic to stenotic aortic valves (see Table).

Event Rates in the Three Groups

\begin{tabular}{|l|l|l|l|l|}
\hline Event & $\begin{array}{l}\text { Normal Aortic Valves } \\
(\mathrm{N}=3919)\end{array}$ & $\begin{array}{l}\text { Aortic Sclerosis } \\
\mathrm{N}=1610)\end{array}$ & $\begin{array}{l}\text { Aortic Stenosis } \\
\mathrm{N}=92)\end{array}$ & $\begin{array}{l}\text { P Value for } \\
\text { Trend }\end{array}$ \\
\hline number (percent) & \multicolumn{3}{|l|}{} \\
\hline Death from any cause & $583(14.9)$ & $353(21.9)$ & $38(41.3)$ & $<0.001$ \\
\hline $\begin{array}{l}\text { Death from } \\
\text { cardiovascular causes }\end{array}$ & $238(6.1)$ & $162(10.1)$ & $18(19.6)$ & $<0.001$ \\
\hline Myocardial infraction & $217(6.0)$ & $123(8.6)$ & $9(11.3)$ & $<0.001$ \\
\hline Angina & $358(11.0)$ & $160(13.0)$ & $17(24.3)$ & 0.001 \\
\hline Congestive heart failure & $337(8.9)$ & $192(12.6)$ & $21(24.7)$ & $<0.001$ \\
\hline Stroke & $238(6.3)$ & $122(8.0)$ & $10(11.6)$ & 0.003 \\
\hline
\end{tabular}

The risk of death from cause, including cardiovascular, was still greater in patients with a sclerotic compared to a normal valve, even when adjustments were made for factors known to be associated with cardiovascular morbidity and mortality. Those subjects without coronary artery disease at baseline and who had aortic sclerosis had a relative risk of 1.40 for myocardial infarction compared to those with normal valves, when adjusted for the baseline factors described above. 


\section{Discussion}

Aortic sclerosis, described by echocardiography, carries an increased cardiovascular morbidity and mortality, and this was particularly pronounced in those people who did not have clinical evidence of coronary artery disease at baseline. The development of clinically relevant outflow tract obstruction to explain these findings is unlikely, although no data are available on subsequent progression of valve pathology. Infective endocarditis was not specifically correlated with aortic sclerosis in this study, but significant endocarditis causing morbidity and mortality would surely have been documented. Finally although the pathophysiologies of aortic valve disease and coronary artery disease have similarities, there are many reasons why it is unlikely that aortic sclerosis directly causes myocardial infarction, and so sclerosis may just be a marker of poor outcome from cardiovascular events.

\section{Additional information}

An editorial accompanies this article.

\section{References}

1. Otto CM, Lind BK, Kitzman DW, Gersh BJ, Siscovick DS: Association of aortic-valve sclerosis with cardiovascular mortality and morbidity in the elderly. N Engl J Med. 1999, 341: 142-147.

This PDF file was created after publication. 